\section{Higher Education Finance in Ghana}

\section{Francis Atuahene}

Francis Atuahene is academic adviser and graduate student supervisor at Western Illinois University. Address: 216 Olson Hall, Macomb, IL 61455, USA.E-mail: FAuahene@wiu.edu.

$\mathrm{H}$ igher education in Ghana has suffered a myriad of challenges such as accessibility, affordability, faculty recruitment and retention, and a deplorable state of infrastructure due to general poverty and macroeconomic instabilities of the country. However, the diminishing financial resources and the growing demand for participation remain the biggest threat to higher education in Ghana.

Statistics provided by Paul Effah, the executive secretary of the National Council for Tertiary Education in Ghana indicate that in 2000 the higher education budget was \$23,870,359, which constituted I2 percent of the total government education discretionary budget distributed among five public universities and eight polytechnics. This state of affairs has adversely affected higher education in the country. As a result, each year over half the qualified applicants seeking entrance to universities and polytechnics do not obtain admission, due to limited academic facilities.

\section{Creation of an Education Trust Fund}

Cognizant of these quagmires and realizing the impact of higher education on national development, the National Union of Ghanaian Students proposed the establishment of a special education trust fund. The government supported this proposal in August 2000, and Parliament passed the Ghana Education Trust Fund bill (GETFund) by raising the already existing value-added tax by 2.5 percent. The objective is to provide financial resources to support educational institutions, provide assistance to genuinely needy and academically talented students, generate monies to support the student loan scheme, and financially support research and development. Initially, the GETFund was projected to generate about 200 billion cedis (US\$54 million) annually. By 2007 , this amount has more than quadrupled. It represented 0.34 percent of gross domestic product in 2003 , and it is projected to increase to $0.8 \mathrm{I}$ percent in 2008.

\section{CONTRIBUtions OF THE GETFUnd}

The GETFund is having a robust impact on the development of universities and polytechnics in the country particularly in areas of infrastructure, which have over the years remained a huge challenge for universities. Institutions at all levels are undergoing a period of renaissance and rapid face-lifting.
Faculty research and development and the promotion of postgraduate studies have been the key focus of the management of the fund. The GETFund has created a scholarship scheme and the Student Loan Trust Fund to improve accessibility at the tertiary level. It has also contributed immensely to the improvement of vocational and technical education in the country by financing the establishment of 20 resource centers and modern equipment to enhance practical skill training. In 2004, for example, the GETFund provided about 224 billion cedis (US\$24,328,467) to finance the transformation and improvement of capacities in the universities and polytechnics through infrastructural development.

Data from the Ministry of Finance and Economic Planning show that these developments have increased admissions at the universities from 40,673 to 53,895 between 2002 and 2003. At the polytechnic levels enrollment increased from I8,459 in 2002 to 23,717 in 2003. Additionally, the GETFund supports the expansion and development of distance education as a means of expanding access. Accordingly, enrollment has risen from 750 in 2002 to 3,618 in 2003 . The minister noted "the increase was supported by an allocation of 839.3 million cedis from the GETFund to facilitate the coordination of distance education in the two main providers of this service, the University of Cape Coast and the University of Education, Winneba." Additionally, over 60 faculty members at tertiary institutions are being sponsored for further studies under the GETFund's Manpower Development Scholarship Scheme.

The diminishing financial resources and the growing demand for participation remain the biggest threat to higher education in Ghana.

\section{Analysis of the Policy Implementation Process}

Despite these great strides, the implementation of the GETFund has also faced some challenges. Alleged misappropriation of the fund has been recorded since its inception. In 2004, the president of the National Union of Ghanaian Students filed a complaint against the government about the transition of the 2.5 percent value-added tax to the GETFund account. A case like this not only impedes the transparency of the fund but also hinders its sustainability. To some degree the GETFund, with its independently appointed board of trustees, is politicized. Even though the board is independent, the administrator who oversees the management of the fund is appointed by the government. But the question is can we entrust public funds to a private entrepreneur? However, the role played by parliamentarians provides control over the management of the fund. Yearly disbursements are subject to strict parliamentary approval, which in essence reduces the autonomy of the board of trustees. 
Additionally, the newly created student loan scheme will make higher education accessible and affordable to students from lower social economic backgrounds. It offers students the opportunity to contribute and share part of the cost of their education. Unfortunately, the high interest rate is likely to put students into bankruptcy in a country faced with unbridled microeconomic instabilities. Also, while providing needsbased loans to students is an improvement over the previous loan scheme, the question remains how can one assess individuals' household income without reliable data? Moreover, awarding a scholarship to an "academically brilliant" student is a step in the right direction, but how do we ensure fairness in a country where a greater percentage of students are those whose parents can provide them with better pretertiary education in addition to supplementary instruction at home?

\section{CONCLUSION}

Despite these challenges, the GETFund is making significant contributions toward higher education development in Ghana in infrastructure, student development, faculty research, and staff support. In 2007 Parliament approved an estimated amount of 582 billion cedis (US\$63,210,57I) by the GETFund to overhaul infrastructure and equipment at the higher education level. It has become one of the richest sources of funds complementing government's budgetary allocation to higher education. However, to sustain the fund for posterity, its sustainability needs to be ensured not only by maintaining transparency but also by providing a legislative instrument to increase the autonomy of the board and improve management efficiency. In summary, the GETFund has the potential for replication in other developing countries facing similar challenges.

\section{Higher Education under a Labour Government}

\section{Michael Shattock}

Michael Shattock is a visiting professor at the Centre for Higher Education Studies, Institute of Education, University of London. E-mail: M.Shattock@ioe.ac.uk.

$\mathrm{T}$ he Labour Party's victory in the general election of I997, fueled by the slogan "Education, Education, Education," was greeted with a wave of popular enthusiasm. For higher education the financial stringencies imposed by the Tories were expected to be significantly alleviated. Labour inherited the recommendations of the National Committee of Inquiry into Higher Education (the Dearing Report), which had been jointly commissioned by the two main political parties to keep higher education from becoming an election issue. These recommendations included a new deal on the financing of students-an issue at the heart of the report. Under the Tory period from I979 to 1997, the unit of resource (i.e., government funding per student) had been reduced by 45 percent as student numbers rose but were funded at marginal cost only. The best that can be said after Io years of Labour is that the government has stabilized state funding per student at the i997 level. The expected uplift occurred only in the area of research; this policy has favored research-intensive universities over the rest. More seriously, the Dearing recommendations on student finance were not accepted, and thus a student fee was introduced. However, the benefit of what should have been an increase in university funding was transferred back to the government in a compensating lower recurrent grant.

Five years later the pressure on university finance forced the government to set up an in-house working party of ministers and civil servants-rather than the more ponderous national commission approach-which produced a white paper, The Future of Higher Education. This document was altogether more radical and controversial than the Dearing Report, proposing a much higher student fee $(£ 3,000)$ coupled with income-based loans funded by the government. Coming at a time when the government was already under fire for its allegedly neoliberal approach to the management of its welfare state inheritance, the proposals aroused serious opposition from within its own party within the House of Commons and were only approved in a knife-edge vote by a majority of five. The concessions wrung by opponents included an agreement to review the level of fees in 2009/io and the establishment of an Office for Fair Access to ensure that access was preserved and that universities committed enough of their increased fee income to bursaries for economically disadvantaged students. Applications for university places dipped slightly in 2005/06, the year before the introduction of the new fee structure but bounded back in the following year, seemingly justifying the government's approach, though the long-term impact of student debt on the economy still needs to be evaluated. The introduction of the new fee levels reinforced the marketization of UK higher education but also brought new and welcome funding into the system. This did not apply in Scotland, however, as the Scottish devolved government rejected fees to the consternation of most Scottish universities, which foresaw an alarming gap emerging between their funding and the rest of the UK university system.

\section{Widening Participation}

From the beginning of its term, the new government sought to demonstrate its commitment to widening access to higher education. The prime minister publicly envisaged the age participation rate rising to 50 percent; in practice it remains stuck 